\title{
ilkokul Öğrencilerinin Sözel Problem Çözerken Kullandıkları Görsel ve Görsel Olmayan Temsillerin İncelenmesi
}

\author{
Emel çiLiNGiR ALTINER', Halil ÖNAL ${ }^{2}$
}

\begin{abstract}
Öz: Araştırmanın amacı, öğrencilerin problem çözerken kullandığı görsel ve görsel olmayan temsilleri belirlemek ve bu temsiller arasındaki varsayılan farklılıkların sözel problem çözme performansını yordayıp yordamadığını incelemektir. Araştırmada iç içe karma desen kullanılmıştır. Tematik ve ilişkisel desen kullanılmıştır. Türkiye'nin Ankara ve Adana illerinde bulunan ilkokullarındaki 4. sınıf öğrencilerinden veriler toplanmıştır. Matematiksel İşlem Testi'ne verilen doğru ve yanlış cevaplar ve bu teste verilen çözümler incelenerek tercih edilen temsil türleri belirlenmiştir. Analizler sonuncunda testteki her bir problemin çözümünde sembolik temsil türü tercih edilmesine rağmen şematik temsil ile çözülmüşsoruların doğru cevaplanma oranlarının daha yüksek olduğu görülmüş̧ür. Bunun yanında araştırmadaki temsil türlerinden sadece şematik temsili tercih etmenin problem çözme performansını yordadığı belirlenmiştir. Bu doğrultuda ilkokul öğretmenlerinin sınıflarında matematiksel problem çözerken görsel temsilleri de çözüm yollarına dâhil etmeleri konusunda öğretmenlere eğitim verilebilir.
\end{abstract}

Anahtar Sözcükler: Sözel Problem Çözme, Görsel ve Görsel Olmayan Temsil, Şematik Temsil, Resimsel Temsil, Sembolik Temsil

\section{Visual and Non-Visual Representations Used by Elementary School Students When Solving Word Problems}

\begin{abstract}
The aim of this study is to determine the visual and non-visual representations that students use while solving problems and examine whether the assumed differences between these representations predict verbal problem solving performance. For this, the mixed-nested design was chosen. Thematic and relational models were used together. Data were collected from 4th-grade students in Ankara and Adana, Turkey. By examining the correct and incorrect answers to the Mathematical Operations Test and the solutions given to this test, the preferred representation types were determined. As a result of the analyses, although the symbolic representation type was chosen for the solution to each problem in the test, it was seen that the correct answer rates for the questions solved with the schematic representation were higher. In addition, it was determined that the preference of only schematic representation, one of the representation types in the research, predicted problem solving performance. Accordingly, primary school teachers can be trained to include visual representations in their solutions while solving mathematical problems in their classrooms.
\end{abstract}

Keywords: Word Problem Solving, Visual and Non-Visual Representations, Schematic Representation, Pictorial Representation, Symbolic Representation

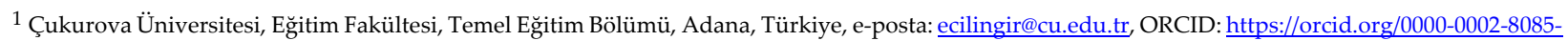
$\underline{553 X}$

2 Burdur Mehmet Akif Ersoy Üniversitesi, Eğitim Fakültesi, Temel Eğitim Bölümü, Burdur, Türkiye, e-posta: halilonal@mehmetakif.edu.tr, ORCID: https://orcid.org/0000-0001-6983-3842
} 
Matematik eğitiminde öğrenciler için kazanılması gereken becerilerden birisi "temsil etme" dir. Matematik eğitiminden önemli bir yeri olan temsil, bireylerin matematiksel bir etkinlik sırasında oluşturdukları gözlenebilen veya zihinlerinde oluşturdukları ürünler, işaretler, objelerdir (Ulusal Matematik Öğretmenleri Konseyi [National Council of Teachers of Mathematics, NCTM], 2000). Aynı zamanda NCTM'ye (2000) göre, matematik öğrenmenin standart süreçleri: (1) problem çözme, (2) muhakeme ve sorgulama, (3) iletişim, (4) ilişkiler ve (5) temsildir. Matematik alanı içinde temsiller, bir öğrenci tarafından deneyim yoluyla geliştirilen matematiksel fikirlerin veya bilişsel şemaların içsel soyutlamaları olarak düşünülebilir (Pape ve Tchoshanov, 2001). Öte yandan sayılar, cebirsel denklemler, grafikler, tablolar, diyagramlar ve çizelgeler gibi temsiller, "duyular üzerinde uyarıcı görevi gören" ve bu kavramları anlamamıza yardımcı olan matematiksel kavramların dişsal tezahürleridir (Janvier ve diğerleri, 1993, s. 81). Aynı zamanda temsil içseldir ve zihinsel bir soyutlamayı dışsallaştırma eylemini ifade eder.

Matematiksel problem çözmede temsil; problem bilgilerinin özetlenmesi, durum / öykü unsurları hakkında kayıt ve akıl yürütme, bellek depolarının boşaltılması, ara hesaplamaların sonuçlarının koordine edilmesi, grafiklerle sayısal veya fonksiyonel ilişkilerin temsil edilmesi ve soyut ilişkileri somutlaştırılması (Zahner ve Corter, 2010) aşamalarında kullanılmaktadır. Bu yüzden problem çözmenin temel unsurlarından biri de temsil etme olarak kabul edilir (Stylianou, 2010). Öğrencilerin matematikte kullandıkları bir takım problem çözme stratejileri olmasına rağmen, iyi problem çözücüler genellikle problemi anlamalarına yardımcı olmak için problemin bir temsilini oluşturabilen öğrencilerdir (van Garderen ve Montague, 2003).Bazı problemler görsel veya sözel bir yaklaşımla etkili bir şekilde çözülebilmesine rağmen, kişinin bir problemi çözerken neden farklı yöntemi seçtiğini tam olarak anlamak için problemin türünün, karmaşıklığının, ilk defa bu soru türüyle karşılaşıyor olmanın, geçmiş yaşantı bilgisinin ve kişinin başarı düzeyinin bilinmesi gerektiği düşünülmektedir.

Mayer (1985) problem çözmenin aşamalarını sıralarken önce problemi temsil etmeyi, sonra görsel temsiller kullanarak somutlaştırmayı, planlama aşamasında işlemleri planlamayı ve son aşamada ise işlemlerin uygulanış sonuçları kontrol etmeyi önermiştir. Matematikte görsel temsil, matematiksel bilgiyi yansıtan modeller oluşturmayı içerir (van Garderen ve Montague, 2003). Görsel temsillerin, bilgiyi işleme sürecinde hayati bir role sahip olduğu bilinmektedir. Aynı zamanda görselleştirme seviyesi önemli bir iletişim aracı olarak görülmektedir (Deliyianni ve diğerleri, 2009). Öğrencinin anlamasını geliştirmek için kullandığı veya oluşturduğu diyagram, şekil veya resim, problemi çözmek için otomatik olarak kafasında büyük bir resim meydana getirmektedir (Rösken ve Rolka, 2006).

Mevcut araştırmalar, görsel temsili "iç görüntülerin (örn., zihinsel görüntüler) ve/veya harici görüntülerin oluşturulması" olarak işlevselleştirmektedir (Hegarty ve Kozhevnikov, 1999; van Garderen ve Montague, 2003). Görsel temsiller ikiye ayrılır birincisi nesnelerin çizimleri olan resimsel gösterimlerdir. Resimsel gösterimler (şematik olmayan gösterimler), problem çözümü için gerekli olmayan, şematik öğeler içermeyen, anlamlı ve yabancı öğeler içerir. Çizime dahil edilen etkileyici ayrıntılar, matematik probleminin çözümü için gereksizdir. İkincisi ise problemlerin bölümleri arasındaki uzamsal ilişkileri temsil eden diyagramlar olan şematik gösterimlerdir (Krawec, 2010). Şekil 1'de resimsel ve şematik temsillere örnek gösterilmektedir. 


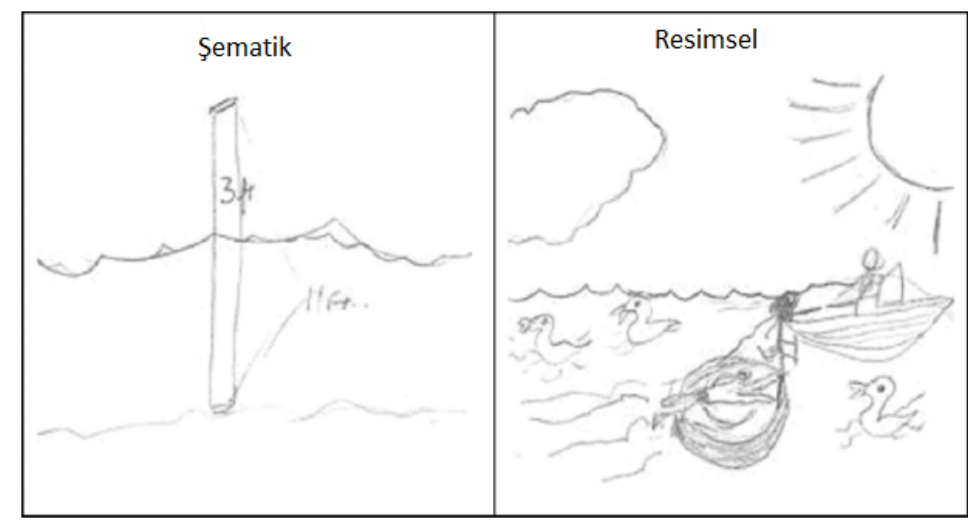

Şekil 1. Şematik ve Resimsel Temsil Türlerine Örnek (Edens ve Potter 2008).

Şekil 1'de gösterilen örnekte olduğu gibi, problem bir gölün derinliğini belirlemeyi içeriyorsa, sudan çıkan bir direğin yüksekliği hakkında bilgi veriliyorsa, şematik olmayan veya resimsel bir temsilde, gölde bir kayık üzerinde yüzen bir çocuğun görüntüsünü içerebilir. Suda yüzen bir teknenin veya ördeklerin bulunması problemin çözümüyle ilgili olmayan ayrıntılardır.

Öğrencilerin problem çözme esnasında kullandıkları görsel temsillerin analizi sonucunda, başarılı olan öğrencilerin problem çözmede genel olarak şematik temsilleri tercih ettikleri ve problemleri çc̈zmekte daha büyük başarıya sahip oldukları ortaya çıkmıştır. Daha başarısız öğrenciler ise daha sık olarak hatalı çözümlere yol açan resimsel temsilleri tercih ettikleri görülmüştür (Guoliang, 2003; Hegarty ve Kozhevnikov, 1999; van Garderen ve Montague, 2003). Benzer olarak, Campbell ve diğerleri (1995) araştırmalarında problem çözmedeki başarının görselleştirmenin türü ile ilgili olduğunu belirtmişlerdir.

$\mathrm{Bu}$ çalışmada ise, problem çözmede temsiller görsel temsiller ve görsel olmayan temsiller şeklinde sınıflandırılmış buna yönelik incelemeler yapılmıştır. Suwarsono' ya (1982) göre, görsel temsiller “... resimler, film şeritleri, bilgisayarlar, filmler, grafikler, kitaplar ve dergiler" kullanarak desteklemeyi içerir. Görsel temsillerle Suwarsono (1982), kâğıt üzerinde ya da zihinde grafik, şekil, resim, figür gösterimini kastetmektedir. Görsel bir çözüm yöntemi, akıl yürütme veya cebirsel yöntemlerde uygulansa bile, çözüm yönteminin önemli bir parçası olarak, bir diyagram olsun veya olmasın görsel temsili içeren bir yöntemdir. Aynı zamanda kişilerin zihinlerinde şekil, resim, tablo gibi temsilleri canlandırmaları yine bu görsel çözüm yöntemine ait olduğu düşünülmektedir. Görsel temsil hem rutin olmayan ve hem de rutin problemlerle olsun, matematik dünyasına kendiliğinden ve işlevsel olarak katkıda bulunmaktadır (Deliyianni ve diğerleri, 2009).

Presmeg (1986), görselleştirici olmayanları "[görsel ve görsel olmayan yöntemlerle çözülebilecek matematiksel problemleri] ... çözme esnasında görsel yöntem kullanmamayı tercih eden kişiler" olarak tanımlamaktadır. Görsel olmayan bir çözüm yöntemi, çözüm yönteminin önemli bir parçası olarak görsel temsilleri içermeyen bir yöntemdir. Görsel olmayan çözümler sembolik temsillerle veya sözel temsillerle oluşturulmaktadır. Sembolik temsiller cebirsel veya sayısal olarak gösterilmektedir. Şekil 2'de sembolik ve sözel temsillere örnek gösterilmektedir. Şekil 2'deki temsillerin problem cümlesi şöyledir: Ali bir ă̆aç dikti ve sonra yol boyunca her 5 adımda başka bir ağaç dikti. Yolun uzunluğu 15 adım olduğuna göre Ali toplamda kaç tane ağaç dikmiştir?

Sembolik temsil

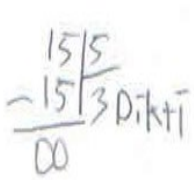

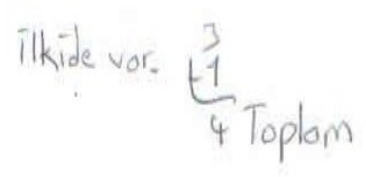

Sözel temsil

15 adımda 5 adım 3 kere vardır. Demek ki 3 ağaç dikmiş. Bir de adım atmaya başlamadan önce dikmişti, toplamda 4 ağaç dikmiş oldu.

Şekil 2. Görsel Olmayan Temsillerin Farklı Türlerine Örnek 
Tüm matematiksel problemler görsel ve görsel olmayan temsillerle çözülebilir. Bazen görsel olmayan çözümlerde görsel ve görsel çözümlerde ise görsel olmayan özellikler bulunur. Bu nedenle çözümler için yapılan analizler bir öğrencinin temel çözüm yöntemine ve tercihine dayanır.

Belirli temsil türlerinin (ör. Görsel veya somut) kullanımının öğrencilerin matematiksel becerilerinin gelişmesine ve gelişmiş problem çözme ve akıl yürütme becerilerinin geliştirilmesine yol açtığı uzun zamandır kabul edilmektedir (Presmeg, 2020). İncelenen araştırmaların neredeyse tümü, görselleştirmenin problem çözme sürecine yardımcı olduğunu göstermektedir. Bazı öğrenciler zor olan problemleri çözerken görsel metodu daha fazla tercih ettikleri (Ho ve Lowrie, 2014; Uesaka ve diğerleri, 2007) ve daha kolay problemler için, görsel olmayan yöntemi kullanmaya meyilli oldukları; (Lowrie, 2012) (Ho ve Lowrie, 2014). Problemleri çözmeden önce görselleştirmeyi kullanarak, öğrencilerin problemleri anladıkları görülmüştür (Nunokawa, 2005). Ancak, görsel olmayan çözümleri tercih eden öğrenciler görselleştirme yönteminin kendileri için herhangi bir fayda sağlamadığını düşünmektedirler (Elia ve Philippou, 2004). Bazı öğrenciler ise, anlamanın çok zor olduğunu düşündükleri için görselleştirme metotlarını problem çözme sürecinde kullanmaktan çekinmektedirler (Uesaka ve diğerleri, 2007). Bu öğrenciler karmaşık bir problemle karşı karşıya kaldıklarında da çözüm üretmek için cebirsel yöntem kullanmayı tercih etmektedirler (Stylianou ve Silver, 2004). Hegarty ve Kozhevnikov (1999) çalışmalarında, matematiksel problem çözmede kullanılan ve görsel -uzamsal temsilin iki türü olan, bir problemde tanımlanan uzamsal ilişkileri kodlayan şematik temsiller ile öncelikle açılanan nesnelerin veya kişilerin görsel temsilini kodlayan resimsel temsiller arasında bir ayrım yapmışlardır. Görseluzamsal temsillerin bu tiplerden birine güvenilir bir şekilde sınıflandırılabileceğini ve tiplerin problem çözme başarısı ile farklı şekilde ilişkili olduğunu göstermişlerdir. Şematik temsillerin kullanımı, matematiksel problem çözmede başarı ile olumlu, resimsel temsillerin kullanımı ise matematiksel problem çözmedeki başarıları ile negatif ilişkili olarak bulmuşlardır. Lowrie ve Kay (2001) ise problem çözme tercihi ve görev zorluğunun öğrencilerin matematik problemlerini temsil etme şeklini etkilediğini bulmalarına rağmen, problem çözen kişinin cinsiyetinin görsel veya görsel olmayan yöntemleri tercih etmesiyle ilişkili olmadığını belirtmiştir. Bu bulgu, geometri ve problem çözme alanlarında cinsiyet farklılıklarına dair çok az kanıt bulan Friedman (1995) tarafından yürütülen kapsamlı bir meta-analizin sonuçlarıyla da tutarlıdır. Bu yüzden bu çalışmada cinsiyet değişkeni ele alınmamıştır.

İncelenen araştırmalara göre ileri matematik (geometri, cebir, olasıllk ve diğerleri gibi) problemleri çözmede görsel temsilden de yararlanmak gerekmektedir (Stylianou ve Silver, 2004). Görsel temsillerle ilgili alanyazının çoğu (Battista, 1990; Haciomeroglu ve diğerleri, 2013; Lean ve Clements, 1981; Moses, 1977; Suwarsono, 1982), iyi yapılandırılmış bir temsilleme türünün öğrenci başarısını destekleme olasılığının daha yüksek olacağını düşündürmektedir. Çözüm yöntemleri tercihleri ile matematiksel performanslar arasındaki ilişkiyi incelemek için çeşitli araştırmalar yapılmasına rağmen halen bu konu ile ilgili kesin sonuçlara ulaşılamamıştır (Mainali, 2021). İlkokul (Moses, 1977) ve ortaokul (Suwarsono, 1982) öğrencileriyle yapılan çalışmalarda çözüm yöntemleri tercihlerinin matematiksel performans üzerinde önemli bir etkisi olmadığını da bulmuştur (Mainali, 2019; Pitta-Pantazi ve Christou, 2009). Haciomeroglu ve diğerleri (2009) ise görsel çözüm yöntemlerini kullanan öğrencilerin performanslarının daha düşük olduğunu bulmuşlardır. Benzer olarak Lean ve Clements (1981) ve Hegarty ve Kozhevnikov (1999) öğrencilerin tercih ettikleri temsillerin matematiksel performansları üzerinde önemli bir etkisi olduğunu bulmuşlardır. Ayrıca sözel temsili kullanan öğrencilerin görsel temsili kullanan öğrencilere göre önemli ölçüde daha iyi performans gösterdiğini ortaya koymuştur. Bu da Lowrie ve Kay'in (2001) bulgularıyla çelişmektedir. Hegarty ve Kozhevnikov (1999) ve Kozhevnikov ve diğerleri, (2002) çalışmalarında görsel temsili şematik ve resimsel olarak iki temada incelemiş şematik temsil türünü seçen öğrencilerin daha başarılı olduklarını belirtmişlerdir. Görüldüğü üzere benzer çalışmalar yapılmasına rağmen farklı sonuçlar bulunmuş görsel temsillerin performansı etkilemediği veya performansı düşürdüğü sonuçlarında iki tür görselleştiriciyi (resimsel ve şematik) hesaba katmadıklarını ve bunun da görsel temsil tercihleri ile matematiksel performans arasındaki ilişkileri bulamamalarına yol açtığ1 söylenebilir. Bunun yanında problem türlerine (zorluk ve kolaylık) göre tercih edilen temsil türleriyle ilgili yurtdışında yapılmış bazı çalışmalarda öğrenciler zor problemleri çözmede görsel temsilleri kullanırlarken (Uesaka ve diğerleri., 2007; Ho ve Lowrie, 2014) bazı çalışmalarda ise zor ve karmaşık problemlerde görsel olmayan temsilleri tercih ettikleri (Elia ve Philippou, 2004; Uesaka ve diğerleri,2007; Stylianou ve Silver, 2004) 
gözlenmiştir. Ancak Türkiye'de böyle çelişkili durumların incelendiği ilkokul öğrencilerinin problem çözerken kullandıkları farklı temsil türlerini inceleyen (Ergan ve Özsoy, 2021; Kılıç, 2010) araştırmalar sınırlıdır. Bu çalışma ile bu tartışmalı durumun özellikle ulusal bağlamda alan yazına katkı sağlayacağı düşünülmektedir. Bu doğrultuda çalışmada öğrencilerin sözel problem çözerken kullandığı görsel ve görsel olmayan temsillerin belirlenmesi ve bu temsiller arasındaki varsayılan farklılıkların sözel problem çözme performansını yordayıp yordamadığının incelenmesi amaçlanmaktadır. Bu amaç doğrultusunda aşağıdaki sorulara cevap aranacaktır.

1. Öğrenciler sözel problemleri çözerken hangi görsel ve görsel olmayan temsil türlerini kullanmaktadır? Hangi temsil türünü kullanarak doğru cevaplar vermektedir?

2. Öğrencilerin sözel problem çözmede kullandıkları temsil türleri öğrencilerin problem çözme performanslarını yordamakta mıdır?

\section{Yöntem}

Araştırmanın amacına uygun olarak incelenecek olan parametreler öğrencilerin problem çözme esnasında tercih ettikleri görsel ve görsel olmayan tercihlerin belirlenmesi ve bu tercihlerine göre sözel problem çözmedeki performanslarını yordaması incelenmiştir. Bunun için nitel araştırma yönteminin ve nicel araştırma yönteminin bir arada kullanıldığı iç içe karma desen tercih edilmiştir. Bu doğrultuda tematik ve ilişkisel model birlikte kullanılmıştır.

\section{Katılımcilar}

Araştırmaya Adana ve Ankara illerindeki devlet okullarında öğrenim görmekte olan 225 dördüncü sınıf öğrencisi katılmıştır. Öğrencilerin araştırmacıların yaşadığı illerden seçilmesi ve bu illerdeki birlikte çalışma yapmaya istekli öğretmenlerin araştırmaya katılması sebebiyle kolay ulaşılabilir örneklem yoluyla katılımcılar belirlenmiştir. Problem çözme ilkokulun ilk yıllarından itibaren kazanılan bir süreçtir. Bu araştırmada dördüncü sınıf öğrencilerinin tercih edilmesinin sebebi dördüncü sınıf öğrencilerinin problem çözerken ilkokulun diğer kademelerine göre kendi özgün problem çözme stratejileri geliştirebilme düzeylerinin daha gelişmiş olacağının düşünülmesidir (Mainali, 2021). Araştırmada kolay ulaşılabilir örnekleme yöntemi kullanılmıştır.

\section{Veri Toplama Araci}

Sözel problemler olarak, Hegarty ve Kozhevnikov'un (1999) geliştirdiği ve Çilingir-Altıner ve Doğan'ın (2018) ilkokul dördüncü sınıf öğrencileri için uyarladığı 11 soruluk Matematiksel İşlem Testi kullanılmıştır. Matematiksel İşlem Testi gerekli aritmetik işlemleri yapmalarını sağlamak ve öğrencilerin sözel problemin problem çözmede belirleyici bir faktör olma olasılığını dışlamak için testteki sorular kolay ve öğrencilerin düzeyine uygun sorulardan oluşturulmuş ve neredeyse her öğrenci tarafından çözülebilir düzeydedir. Testin iç tutarlılı katsayısı daha önceki çalışmalarda ,78 tutarlılık düzeyinde bulunurken (Hegarty ve Kozhevnikov, 1999) bu çalışma için Cronbach alfa değeri , 87 olarak bulunmuştur. Matematiksel İşlem Testi ile ilgili problem maddeleri Ek 1'de verilmiştir.

$\mathrm{Bu}$ test ile ilkokul dördüncü sınıf öğrencilerinin sözel problemleri doğru çözüp çözemediklerine bakılarak aynı zamanda öğrencilerin kullandıkları temsiller kategorilere ayrılarak incelenmiştir. Bu kategoriler resimsel temsil, şematik temsil, sözel temsil, sembolik temsil ve zihinden (öğrenci işlem yapmadan sadece cevabı yazmışsa) çözmedir. Araştırmaya katılan öğrencilerin \%25'inin kağıtları incelenerek temsil türlerinin belirlenmesinde iki bağımsız kodlayıcı tarafından değerlendirmeler yapmıştır. Bu değerlendirmeler arası güvenirlik Cohen's Kappa değeri ile belirlenmiştir. Cohen Kappa Katsayıları ,86 ve üzeri değerler almıştır ve bu değerler istatistiksel açıdan anlamlı bulunmuştur $(\mathrm{p}<, 001)$. Bu değerlerin ortalaması ise ,96'dır.

\section{Kodlama}

Araştırmada araştırma sorularına yanıt aranmak için iki farklı kodlama yapılmıştır. Öncelikle soruların nitel analiz yöntemlerinden doküman analizi için her bir soru maddesi (1) yapılan görsel temsilin türü (resimsel-şematik) ve doğru cevaplanıp cevaplanmadığı (2) görsel olmayan temsilin türü (sembolik-sözel) ve 
doğru cevaplanıp cevaplanmadığı (3) temsilin harici mi (yani, kâğıt ve kalemle bir çizim) veya dâhili mi (yani zihinsel) ve doğru cevaplanıp cevaplanmadığı şeklinde kodlanarak incelenmiştir. Örneğin sözel bir problemin çözümünde öğrenciler bir görüntü veya şema çizdiyse veya zihinsel bir görüntü bildiriyorsa, bu şekilde bir problemdeki çözümün görsel mi resimsel mi olduğuna bakılmıştır ve ardından öğrencinin soruyu doğru cevaplayıp cevaplamadığına bakılmıştır. Eğer öğrenci hem şematik bir temsil kullanmış hem de soruyu doğru cevaplandırmışsa soru maddesi "şematik doğru" olarak kodlanmıştır. Bunun yanında incelenmek istenen araştırmanın nicel yönünü analiz etmek amacıyla öğrencinin testteki toplam doğru sayısı öğrencinin problem çözme performans puanını, testte tercih ettiği resimsel temsil sayısı resimsel temsil puanını, şematik temsil sayısı şematik temsil puanını, sembolik temsil sayısı sembolik temsil puanını, sözel temsil sayısı sözel temsil puanını, zihinsel temsil sayısı ise zihinsel temsil puanını oluşturmaktadır.

\section{Verilerin Analizi}

Öğrenciler sözel problemleri çözerken hangi görsel ve görsel olmayan temsil türlerini tercih ettiklerini ve bu tercihleri sonucunda soruyu doğru yapıp yapmadıklarını incelemek amacıyla tematik analiz kullanılmıştır. Bu analizle her bir soru için öğrencilerin genelde hangi temsil tipini seçtikleri, bu temsil tipinin tercih edilme oranı ve farklı temsil tiplerinde ne kadar doğru cevaplama oranına sahip oldukları belirlenmiştir. Diğer bir aşamada ise öğrencilerin sözel problem çözmede kullandıkları temsil türleri öğrencilerin problem çözme performanslarını yordayıp yordamadığını belirlemek için Çoklu Regresyon analizi yapılmıştır. Öncelikle normallik varsayımını sağlamak için mahalanobis uzaklıklarına bakılmıştır. Nicel analiz için altı uç değer çıkarılmıştır. Sonrasında ise korelasyonel analiz yapılmıştır. Birbiriyle ilişkili bulunan ve çoklu bağlantı sorunu yaratmayan değişkenlerle de çoklu doğrusal regresyon analizi yapılmıştır. Analiz sonucunda çoklu regresyon analizi için gerekli sayıltıların sağlandığ1 görülmüştür (İkili korelasyon <,80; R2> ,20; CI> 30; VIF $>10)$.

\section{Bulgular}

Araştırmada ele alınan birinci araştırma sorusu için öğrenci tercih ettikleri temsil türleri her bir soru için ayrı ayrı analiz edilmiştir. Öğrenciler sözel problemleri çözerken hangi temsil türlerini kullandıkları ve hangi temsil türünü kullanarak doğru cevaplar verdikleri ortaya çıkarılmaya çalışmıştır. Matematiksel İşlem Testindeki sorulara hangi temsil türünde cevap verildiği ve doğru cevapların hangi temsil türünde daha fazla olduğu aşağıdaki şekillerde gösterilmiştir.

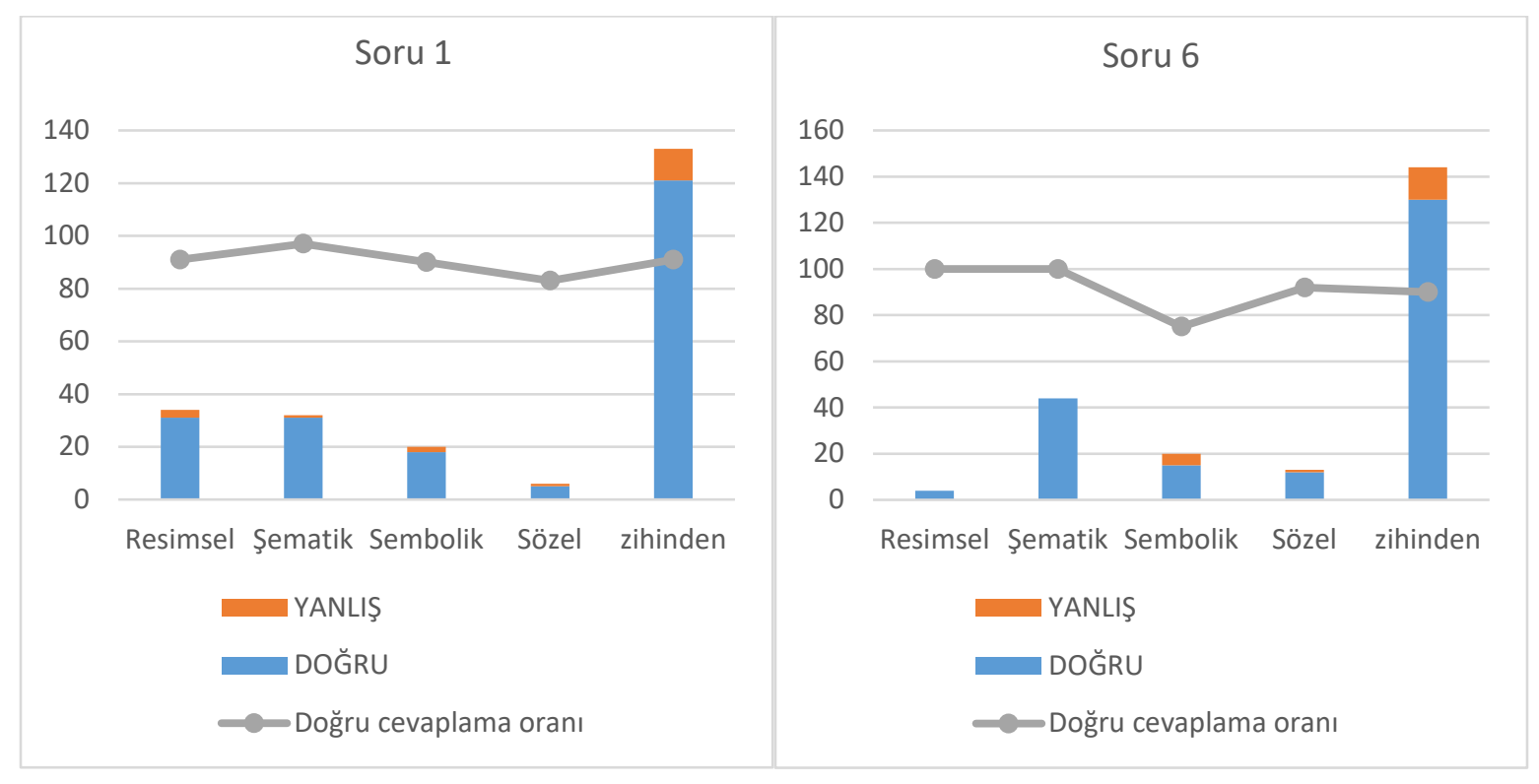

Şekil 3. 1. ve 6. Soruların Tematik Analizi

Şekil 3 incelendiğinde Matematiksel İşlem Testi sorularından 1. ve 6. soruların zihinden çözmenin tercih edildiği ve bu sorularda hangi temsil türü seçilirse seçilsin doğru cevaplama oranının yüksek olduğu 
görülmüştür. 1 . soru için; resimsel $=0,91$, şematik $=0,97$, sembolik $=0,90$, sözel $=0,83$, zihinden $=0,91$. 6 . soru için ise resimsel $=1,00$, şematik $=1,00$, sembolik $=0,75$, sözel $=0,92$, zihinden $=0,90$. Şekil $4^{\prime}$ te 6 . soruya verilen cevaba örnek bulunmaktadır.

\section{PROBLEM 6:}

Deniz'in parası Canan'ın parasından fazladır. Mete'nin parası ise Canan'in parasından azdır. Kimin parası daha fazladır?

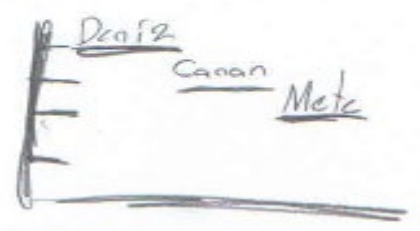

Şekil 4. 6. Soruya Verilen Cevap

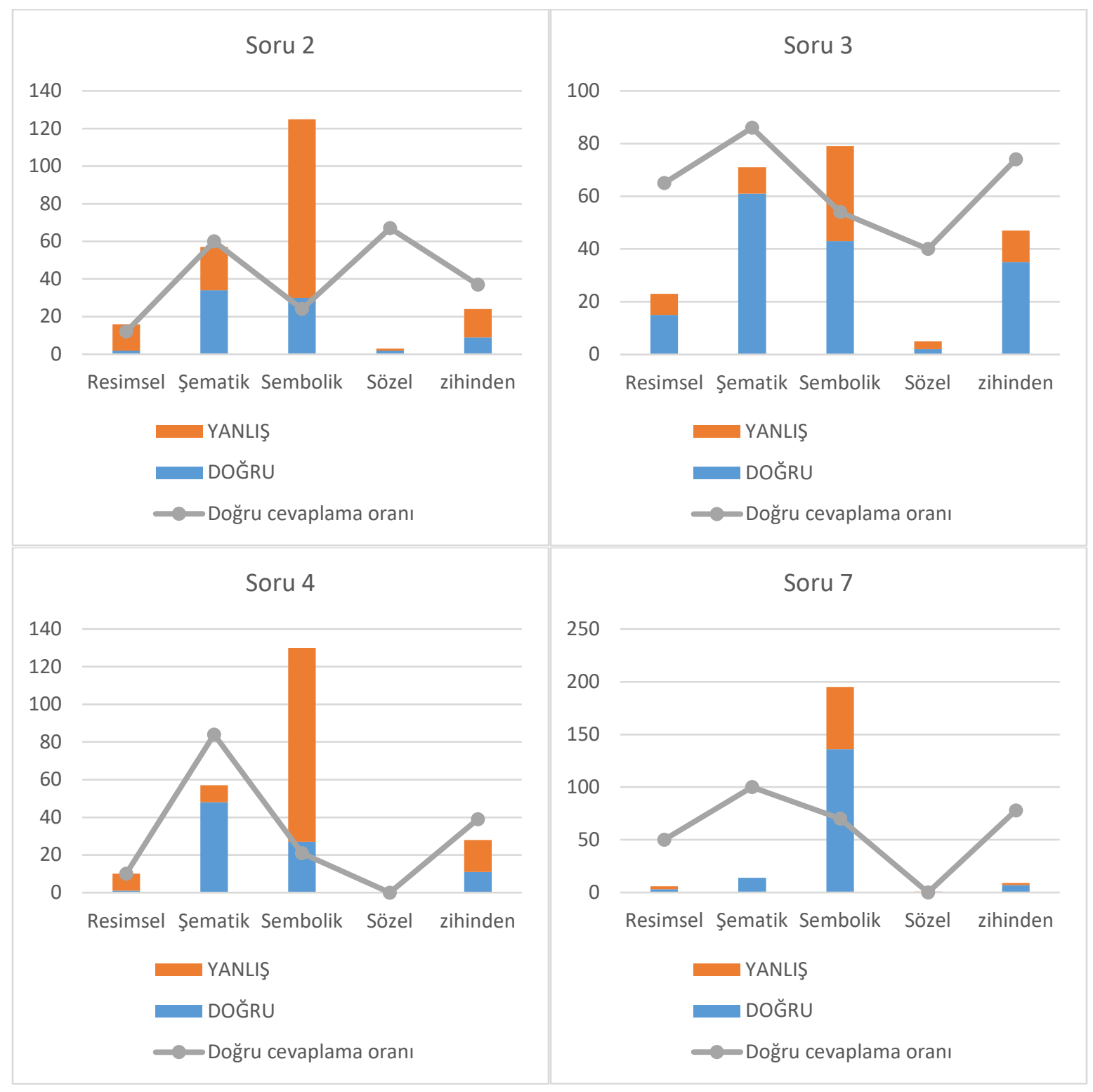




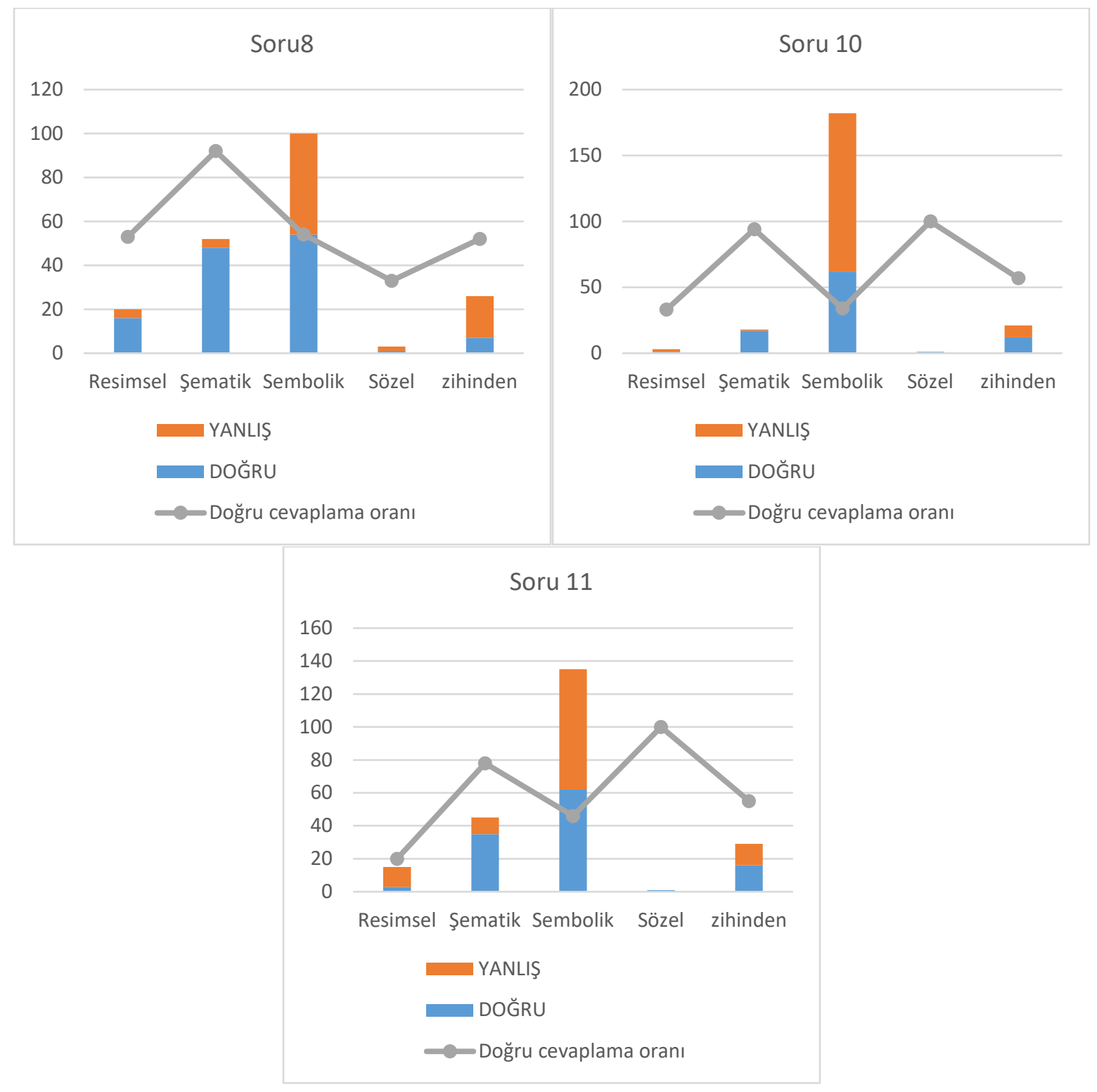

Şekil 5. 2., 3., 4, 7., 8., 10. ve 11. Soruların Tematik Analizi

Şekil 5 incelendiğinde MiT sorularından 2.,3., 4, 7., 8., 10. ve 11. sorular için problem çözümlerinde sembolik temsilin tercih edildiği ancak şematik temsilin tercih edenlerin doğru cevaplama oranlarının daha yüksek olduğu görülmüş̧ür. 2. soru için sembolik temsili tercih eden öğrenci sayısı $=125$, şematik temsili tercih eden öğrenci sayısı $=57$, sembolik temsili doğru cevaplama oranı $=0,24$, şematik temsili doğru cevaplama oranı $=0,60.3$. soru için sembolik temsili tercih eden öğrenci sayısı $=79$, şematik temsili tercih eden öğrenci sayısı $=71$, sembolik temsili doğru cevaplama oranı $=0,54$, şematik temsili doğru cevaplama oranı $=0,86.4$. soru için sembolik temsili tercih eden öğrenci sayısı $=130$, şematik temsili tercih eden öğrenci sayısı $=57$, sembolik temsili doğru cevaplama oranı $=0,21$, şematik temsili doğru cevaplama oranı $=0,84.7$. soru için sembolik temsili tercih eden öğrenci sayısı $=195$, şematik temsili tercih eden öğrenci sayısı $=14$, sembolik temsili doğru cevaplama oranı $=0,70$, şematik temsili doğru cevaplama oranı $=1,00$. 8. soru için sembolik temsili tercih eden öğrenci sayısı $=100$, şematik temsili tercih eden öğrenci sayısı $=52$, sembolik temsili doğru cevaplama oranı $=0,54$, şematik temsili doğru cevaplama oranı $=0,92$. 10. soru için sembolik temsili tercih eden öğrenci sayısı $=182$, şematik temsili tercih eden öğrenci sayısı $=18$, sembolik temsili doğru cevaplama oranı $=0,34$, şematik temsili doğru cevaplama oranı $=0,94$. 11 . soru için sembolik temsili tercih eden öğrenci sayısı $=135$, şematik temsili tercih eden öğrenci sayısı $=45$, sembolik temsili doğru cevaplama oranı $=0,46$, şematik temsili doğru cevaplama oranı $=0,78$. Şekil $6{ }^{\prime}$ da 2 . soruya verilen cevaba örnek 
verilmiştir.

\section{PROBLEM 2:}

Uçan balon ilk önce yerden 20 metre yükseldi. Sonra să̆a doğru 10 metre ilerledi, sonra 10 metre aşağıya düştü. Daha sonra sağa doğru 5 metre ilerledi ve sonunda düz bir şekilde yere düştü. Balon başlangıç noktasından ne kadar uzaktadır?

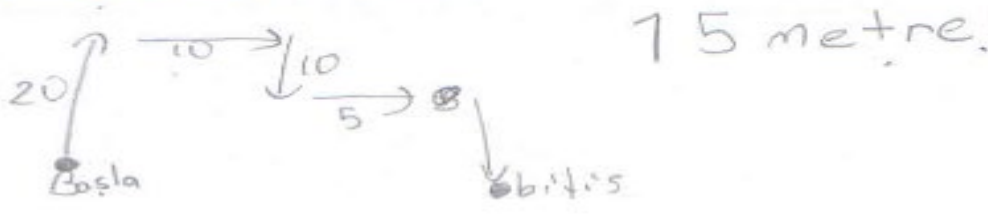

Şekil 6. 2. Soruya Verilen Cevap

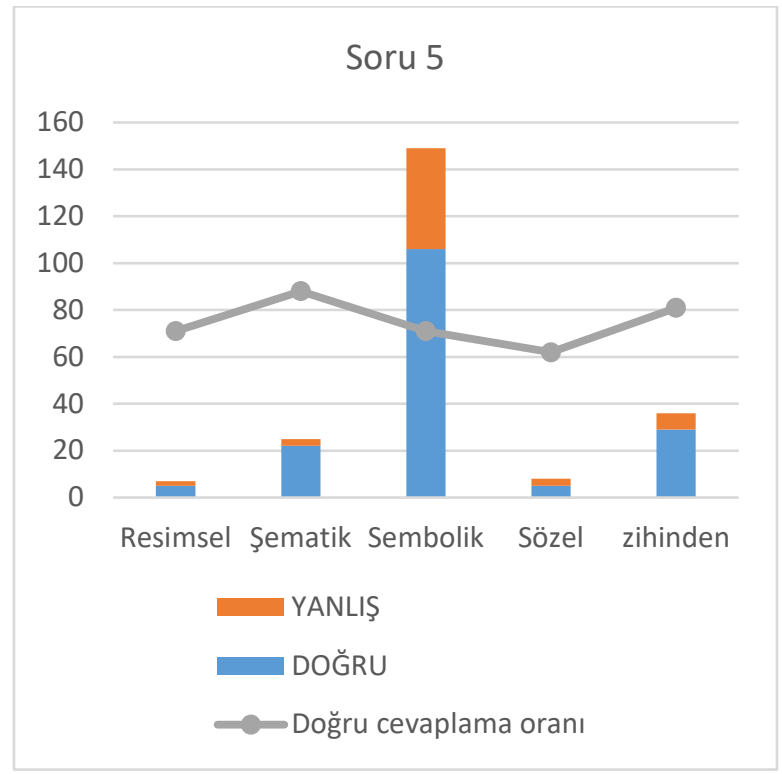

Şekil 7. 5. Sorunun Tematik Analizi

Şekil 7'ye göre 5. soruda sembolik temsil daha çok tercih edilmesine rağmen bu sorunun şematik veya zihinden çözüldüğünde daha çok doğru cevaplandığı belirlenmiştir (şematik = 0,88, zihinden $=0,81$ ). Şekil 8 'de 5. soruya verilen cevaba örnek verilmiştir.

\section{PROBLEM 5:}

Dilara, Sıla ve Onur'un doğum günleri 1 Ocaktır. Ancak Dilara, Sıla'dan 1 yaş büyüktür ve Dilara, Onur'dan 3 yaş küçüktür. Eğer Onur 10 yaşında ise, Sıla kaç yaşındadır?

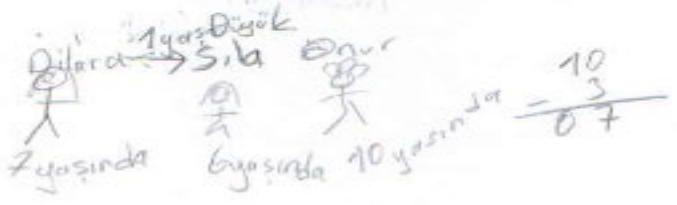

Şekil 8. 5. Soruya Verilen Cevap 


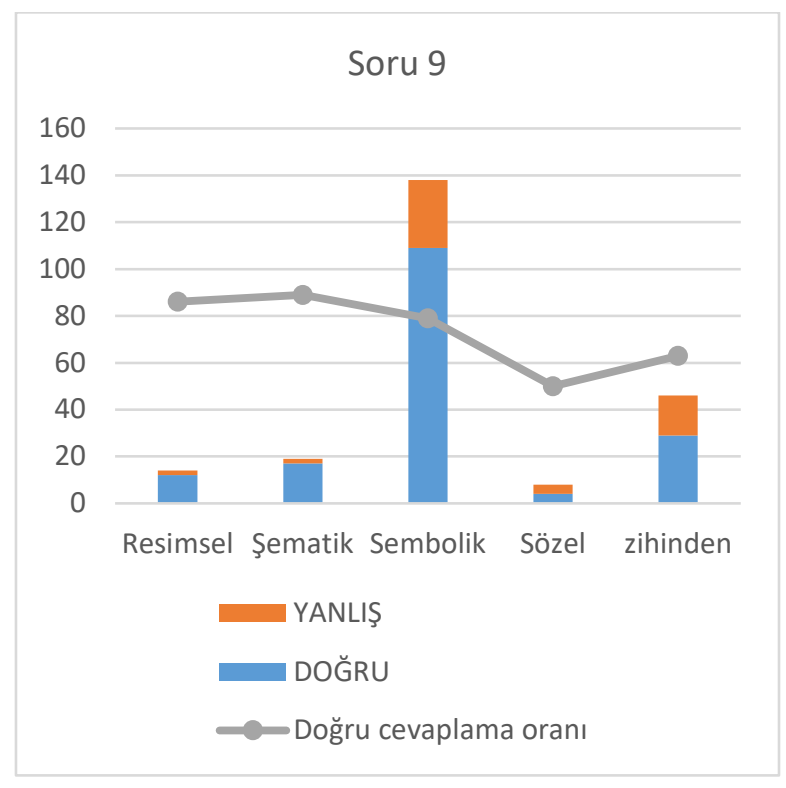

Şekil 5. 9. Sorunun Tematik Analizi

Şekil 9'da ise 9. sorunun tematik analizi yer almaktadır. Bu soruda yine sembolik temsil ile çözüm daha fazla tercih edilmiş ancak şematik ve resimsel temsil ile çözmeyi tercih edenler daha fazla doğru cevaplama oranına sahip olmuştur (şematik $=0,90$, resimsel $=0,86$ ). Şekil 10' da 9. soruya verilen cevaba örnek verilmiştir.

\section{PROBLEM 9:}

Mustafa atım 2 inek karşılığında Halil'e verdi. Daha sonra, Mustafa her bir ineğini 3 koyun karşılığında Ayşe'ye verdi. Buna göre Mustafa kaç tane koyun almıştır?

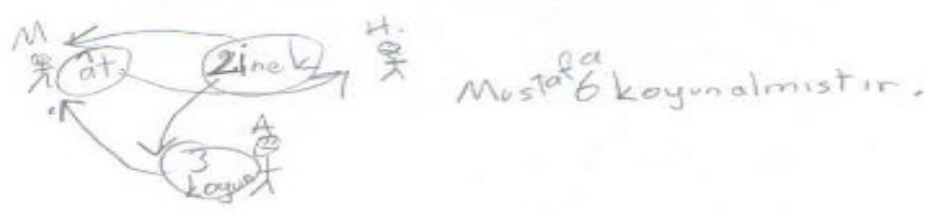

Şekil 10. 9. Soruya Verilen Cevap

Tematik analiz sonuçlarına genel olarak bakıldığında kolay problemlerde öğrencilerin daha çok zihinden problem çözmeyi tercih ettiği bunun yanında hangi temsili seçerlerse seçsinler soruyu doğru cevaplama oranlarının yüksek olduğu görülmüştür. Daha zor soruların çözümünde ise öğrencilerin daha çok sembolik temsil kullanmayı tercih ettikleri görülmüş ancak öğrencilerin bu soruları şematik temsil ile çözdüklerinde soruları doğru cevaplama oranlarının daha yüksek olduğu görülmüştür.

Tablo 1. Korelasyon Analizi Sonuçları

\begin{tabular}{llllccccc}
\hline Değişken & M & SD & $\mathbf{1}$ & $\mathbf{2}$ & $\mathbf{3}$ & $\mathbf{4}$ & $\mathbf{5}$ & $\mathbf{6}$ \\
\hline $\begin{array}{l}\text { 1. Problem Çözme Performansı (MPI) } \\
\text { Yordayıcı Değişkenler }\end{array}$ & 7,014 & 2,619 & - &, $094^{* * *}$ &, $534^{*}$ &,$- 353^{*}$ &,$- 010^{* * *}$ &,$- 164^{* *}$ \\
2. Resimsel Temsil & & & & & & & & \\
3. Şematik Temsil & 0,648 & 1,045 & - &, 282 &,- 357 &, 033 &,- 290 \\
4. Sembolik Temsil & 1,941 & 2,606 & & - &,- 617 &,- 007 &,- 423 \\
5. Sözel Temsil & 5,749 & 2,955 & & & - &,- 002 &,- 371 \\
6. Zihinden Çözme & 0,174 & 0,446 & & & & - &,- 167 \\
\hline
\end{tabular}

${ }^{*} \mathrm{p}<, 001,{ }^{* *} \mathrm{p}<, 05,{ }^{* * *} \mathrm{p}>, 05$

Tablo 1 incelendiğinde problem çözme performansı ile şematik temsil, sembolik temsil ve zihinden çözme değişkenleri arasında anlamlı ilişki bulunmuştur. Problem çözme performansı ile şematik temsil arasında pozitif yönde orta düzeyde $(r=0,53)$ bir ilişki bulunurken sembolik $(r=-0,35)$ ve zihinden $(r=-0,16)$ değişkeni ile düşük ve negatif yönde bir ilişki bulunmuştur. Problem çözmenin resimsel ve sözel temsil ile olan ilişkisi anlamlı bulunmamıştır ( $\mathrm{p}>, 05)$. Bu yüzden çoklu regresyon analizine resimsel temsil, sembolik 
temsil ve zihinden değişkenleriyle devam edilmiştir. Tablo 2'de çoklu regresyon analizinden elde edilen bulgular verilmiştir.

Tablo 2. Problem Çözme Performansının Yordanmasına Yönelik Çoklu Regresyon Analizi Sonuçları

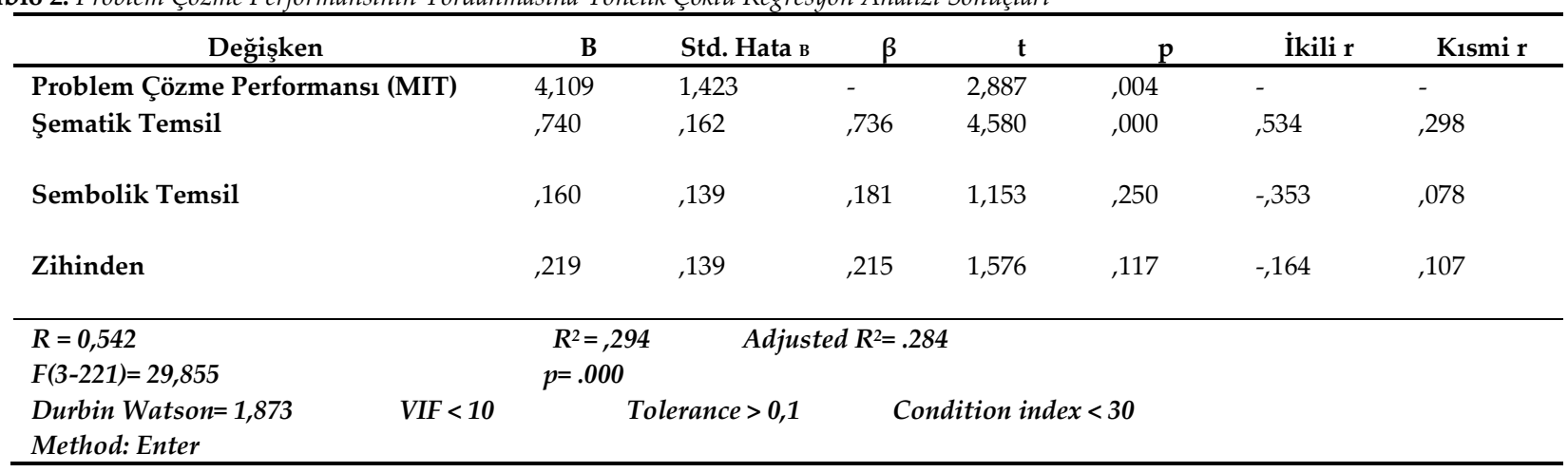

Tablo 2'ye göre yordayıcı değişkenlerle bağımlı değişken arasındaki kısmi korelasyonlar incelendiğinde diğer iki değişken kontrol edildiğinde problem çözme ile şematik temsil arasındaki korelasyonun pozitif ve ortanın altında $(r=0,30)$, problem çözme ile sembolik temsil arasındaki korelasyonun ile pozitif ve düşük $(r=$ $0,08)$ ve problem çözme ile zihinden değişkeni arasındaki korelasyonun pozitif ve düşük $(r=0,11)$ olduğu görülmektedir. Şematik temsil, sembolik temsil ve zihinden çözme değişkenleri birlikte, problem çözme performansı ile orta düzeyde ve anlamlı bir ilişki vermektedir, $R=0,542, R 2=0,294, p<, 01$. Bu üç değişken birlikte, problem çözme performansındaki varyansın yaklaşık \%30'unu açıklamaktadır.

Standardize edilmiş regresyon katsayısına $(\beta)$ göre, yordayıcı değişkenlerin problem çözme performansı üzerindeki göreli önem sırası şematik temsil, zihinden ve sembolik temsildir ( $\beta$ şematik $=0,74$; $\beta$ zihinden $=0,21 ; \beta$ sembolik $=0,18$ ). Regresyon katsayılarının anlamlılığına ilişkin $t$ testi sonuçları incelendiğinde, sadece şematik temsilin problem çözme performansı üzerinde anlamlı yordayıcılar olduğu, zihinden ve sembolik temsilin problem çözme performansı üzerinde anlamlı bir yordayıcı olmadığı görülmüştür $(\mathrm{t}=4,58 ; \mathrm{p}<, 001)$. Bu durumda, problem çözme performansını şematik temsili kullanmanın daha etkili bir şekilde yordadığını söylemek olasıdır. Sembolik temsil ve zihinden çözüm değişkenleri problem çözme performansı üzerinde anlamlı bir yordayıcı değildir.

\section{Sonuç ve Tartışma}

Problem çözme becerilerinin başarılı bir şekilde geliştirilmesi, matematik öğreniminin önemli bir parçasıdır ve öğretmenlerin öğrenciler için birincil endişesidir (Garzon ve Casinillo, 2021). Matematik öğretmenlerinin öğretim stratejileri, öğrencilerin problem çözme becerilerini geliştirmenin anahtarıdır (Leonard, 2018). İyi bir matematikçi, problem durumu üzerine bir anlayış oluşturmada yaklaşımı görselleştirmek ve çözümü planlamada yol göstermek için sıklıkla temsiller kullanmaktadır (Stylianou ve Silver, 2004). Bu doğrultuda araştırmada öğrencilerin tercih ettikleri temsillerin belirlenmesi, hangi temsilleri öğrencinin problemi çözmede yardımcı olduğunun ortaya çıkarılması ve problem çözme performansını en çok hangi temsil türünün etkilediğinin gösterilmesi için bu araştırma yapılmıştır.

Araştırma bulgularına göre öğrencilerin sözel problemleri çözerken hangi temsil türlerini kullandıkları ve hangi temsil türünü kullanarak doğru cevaplar verdikleri incelendiğinde öğrenciler, soruların çoğuna (11 sorudan 9 tanesine) sembolik temsil kullanarak cevap vermişlerdir. Ancak öğrencilerin şematik temsili tercih ettikleri sorularda, soruyu doğru cevaplama oranlarının daha yüksek olduğu gözlenmiştir. Lowrie ve Kay (2001) öğrencilerin sözel problem çözerken tercih ettikleri temsillerin problemlerin zorluğuna göre değiştiğini ve öğrencilerin zor problemi çözmek için görsel temsilleri kullanmayı tercih ettiklerini belirtmiştir. Oldukça karmaşık veya yeni bir durumla karşı karşıya kaldığında, bir öğrenci, problemi çözmek için gerekli bilgiye kolayca erişilebiliyorsa, çözümünde görsel olmayan temsili kullanabilir. Bu çalışmada da öğrenciler daha çok sembolik temsili tercih etmişlerdir. Ancak doğru cevaplama oranı şematik temsile göre düşük kalmıştır. Bunun sebebi, öğrencilere sorulan problemlerin kolay ancak rutin olmayan problemlerden tercih 
edilmesinden kaynaklanmış olabilir.

Araştırma sonuçlarına göre şematik temsili tercih edenlerin soruyu doğru cevaplama oranları diğer temsillere göre daha yüksektir. Benzer olarak Boonen ve diğerleri (2014) araştırmalarında yaptıkları analizler sonucu diğer temsil türlerine (görsel olmayan, resimsel temsiller) göre sadece doğru görsel-şematik temsillerin kullanımının bir sözel probleme daha çok doğru cevap verdiklerini, resimsel ve görsel olmayan temsilleri kullananların ise daha çok yanlış cevap verdiklerini belirtmişlerdir. Bu bağlamda görsel temsilin içeriğinin ve gösteriliş biçiminin de önemli olduğu sonucuna ulaşabilir.

Matematikte görsel temsil, matematiksel bilgileri yansıtan modeller tasarlamayı ve oluşturmayı içerir (van Garderen ve Montague, 2003). Montenegro ve diğerlerine (2018) göre problem çözerken görsel temsil süreci problem çözmede bir başlangıç düzeyi olduğunu, bu temsilleri kullanmanın diğer görsel işlemlerin özelliklerini genişlettiğini, dönüşümleri kolaylaştırdığını ve öğrencilere fayda sağlayan sembolik ve sözel temsillere dönüştürmede esneklik sağladığını belirtmişlerdir. Lowrie ve Kay (2001) de benzer olarak öğrencilerin belirli bir problemi çözmek için belirli bir bilgi birikimine, önceki bir deneyime veya kavrama kapasitesine ulaşabildikleri zaman görsel olmayan uygulamalara eriştiklerini iddia etmişlerdir. Dolayısıyla görsel olmayan temsiller daha karmaşık bir süreç olduğu ifade edilebilir. Buradan da araştırmanın sonuçları da göz önünde bulundurulduğunda öğrencilerin görsel olmayan temsillerle işlem yapmadan önce görsel temsiller ile problem çözmelerinin desteklenmesi gerektiği ve sonrasında gelişim gösterdikçe görsel olmayan temsillerle çözüm stratejileri geliştirmelerine yönlendirilmeleri çıkarımında bulunabilir. Benzer olarak Lowrie ve Clements (2001) ilkokul öğrencilerinin, problemleri görsel temsilleri kullanarak çözme kapasitesini gösterdikten sonra, cebirsel temsiller de dahil olmak üzere sembolik stratejilerle tanışmaları gerektiğini yani görselden görsel olmayana doğru bir geçiş olması gerektiğini belirtmişlerdir. Bundan farklı olarak Anwar ve Rahmawati'ye (2017) göre ise problemi anlamada öğrenciler sözel temsiller önemlidir. Sözel temsiller ile problemi iyi tanımlayabilirler, bu sebeple öğrenciler tarafından oluşturulan semboller çok faydalıdır ve öğrencilere problem çözmede yardımcı olur. Sözel temsil öğrenciler tarafından problemi anlama aşamasında da kullanılır. Sözlü temsil biçimi, daha çok anladıkları bir dille bir problemdeki bilinen tüm bilgilerin yazılmasıyla ortaya çıkar. Bilinen bilgilere dayanarak, öğrenciler yazılı cümleleri kullanarak bir dizi hesaplama planlayabilir ve uygulayabilir, böylece problemler doğru bir şekilde çözülebilir.

Araştırmanın bir diğer bulgusu ise öğrencilerin problem çözme performanslarının sözel temsil ve resimsel tercihleri ile ilişkili olmadığı görülmüştür. Bunun yanında soruyu zihinden çözmenin veya sembolik temsil tercih ederek çözmenin problem çözme performansı ile düşük ve negatif yönde bir ilişkisi olduğu ortaya çıkmıştır. Ayrıca öğrencilerin problem çözmede şematik temsili tercih etmeleri problem çözme performanslarını anlamlı bir şekilde etkilediği görülmüştür. Analizler sonucunda sadece şematik temsilin problem çözme performansı üzerinde anlamlı yordayıcı olduğu ortaya çıkmıştır. Bu durum çalışmanın nitel kısmını ayrıca desteklemektedir. Benzer olarak Hegarty ve Kozhevnikov (1999) de şematik temsillerin kullanımını, matematiksel problem çözmede başarı ile olumlu, resimsel temsillerin kullanımını ise matematiksel problem çözmedeki başarıları ile negatif ilişkili olarak bulmuşlardır. Benzer olarak Boonen ve diğerleri (2014) yaptıkları çalışmada öğrencilerin doğru bir görsel-şematik temsil kullandıklarında, bunun bir sözel problemi doğru çözme şansını yaklaşık altı kat arttırdığını belirlemişlerdir. Muhtemelen bunun nedeni, bu tür görsel temsilin, anahtar değişkenler arasındaki doğru ilişkiler kurmasının yanı sıra problem durumunun eksiksiz, tutarlı ve oluşturan kişi için anlamlı bir görüntüsünü içermesidir. Buna karş1lık, Boonen ve diğerlerinin (2014) çalışmasında hatalı görsel-şematik temsillerin ve resimli temsillerin kullanılmasının, problem çözme şansını sırasıyla 2,94 ve 2,78 kat azaltmıştır. Resimli temsiller bazen problem üzerindeki ilgiyi farklı noktalara çekmekte, problem cümlesinin ana hedefinden şaşırtmaktadır. Problemde bahsi geçen nesnelerin, kişilerin üzerinde durulmasına sebep olabilmektedir. Örneğin problemde bahsi geçen ağacın tüm ayrıntılarıyla gösterilmeye çalışılması sırasında dallarına, yapraklarına odaklanılması, bir kişinin saçlarına, kıyafetlerine odaklanılması sonucu sorunun ana hedefinden soyutlanılmaktadır. Bu da muhtemelen problemi çözen öğrencilerin dikkatini problemin tutarlı bir modelini oluşturmaktan ve çözümle ilgili unsurlar arasındaki uygun ilişkiler kurmaktan uzaklaştırmasına sebep olmaktadır. Bunun yanında probleme uygun ve amaca hizmet eden resimli bir modelin oluşturulmasıyla öğrenciler problemi daha iyi anlarlar ve 
matematiksel düşünme ve problem çözme becerilerini geliştirirler. (Garzon ve Casinillo, 2021). Lindner (2020) problemlerin resimli temsillerle birlikte öğrencilere sorulmasında problem çözme memnuniyetini arttırdığını ve problemin çözüm başarısını arttırdığını belirtmiştir.

$\mathrm{Bu}$ çalışmanın bulgularının ilkokul matematik öğretimi için değerli çıkarımlara sahip olduğu düşünülmektedir. Çalışma sonuçlarına göre, öğrencilerin görsel temsil kullanılmamasının sebebi olarak öğrenciler matematiksel sözel problem çözme sırasında görsel temsiller oluşturmayı gereksiz veya zor bulmuş veya öğrencilere görsel temsillerin kullanımı etkili bir şekilde öğretilmemiş olabilir. Öğrencilerin bir sözel problemi temsil etmek ve çözmek için çözümlerin sadece \%18'inde görsel bir temsilden yararlanması dikkat çekicidir. Buna rağmen şematik temsil kullanan öğrencilere kıyasla, görsel olmayan temsiller kullanan öğrencilerin problem çözme performanslarının daha düşük olması endişe vericidir. Bunun sebebi genel olarak, Johar ve Lubis'e (2018) göre öğrencilerin temsilleri hatalı kullanmada yüksek yüzdeye sahip olmaları, öğrencilerin temsil gerektiren problemlere alışkın olmaması, öğrencilerin PISA ve TIMSS gibi uluslararası sınavlarda sorulan problemler tarzındaki problemleri çözmeye alışkın olmaması, öğretmenlerin öğretim esnasında rutin olmayan problemleri çözmeye alışık olmamasından kaynaklanmaktadır. Hal bu ki, farklı temsil türlerinin kullanılması genellikle karmaşık matematiksel fikirlerin farklı yönlerini aydınlatacağı düşünülmektedir. Ahmad ve diğerleri (2010) öğrencilere herhangi bir matematiksel sözel problem çözmeyi anlamalarına yardımcı olmak için farklı temsil türlerini kullanma fırsatı verilmesi gerektiğini belirtmiştir.

Yalnızca tek taraflı tercih edilen matematiksel problem çözme temsilinin geliştirilmesi, matematik problemlerini diğer perspektiften görme fırsatına sahip olmadıkları için öğrencilerin dar matematiksel gelişimleri ile sonuçlanır. Bu nedenle matematik dersinde öğretim stratejileri, öğrencilerin görsel ve görsel olmayan çözüm temsilleri arasındaki bilgi ve becerilerindeki dengeyi geliştirmeye odaklanmalıdır. Aynı zamanda öğretmenlerin öğrencilerde farklı temsil biçimini kullanabilecekleri becerileri geliştirecekleri etkinlikleri kullanmaları önemlidir. Öğrencilerin temsil tercihi çoğunlukla öğretmenlerinin onlara sınıfta ne öğrettiklerine bağlıdır. Bu nedenle araştırmacıların öğretmenlere önerisi, matematiksel sözel problemleri anlamalarına ve çözmelerine yardımcı olabilecek temsiller konusunda da dikkatli olmaları ve sınıflarında matematik öğretme ve öğrenmeye görsel ve görsel olmayan temsilleri nasıl entegre edilebileceği konusunda hazırlıklı olmaları şeklindedir. Bunun yanında matematik programı geliştiricilerinin de programda çoklu temsil türlerinin kullanımına yer vermeleri önerilmektedir. Gelecek çalışmalarda ise, bu tarz çalışmaların farklı yaş gruplarında tekrarlanmasına ve temsil türlerini tercih etmeyi etkileyen faktörlerin belirlenmesine yönelik yeni çalışmalar yapılabilir.

\section{Yazarların Beyanı}

Araştırmacıların katkı oranı beyanı: Araştırmanın verileri her iki yazar tarafindan da toplanmış analiz süreci ortak gerçekleştirilmiştir. Her iki yazar da araştırmanın giriş, yöntem, bulgular, sonuç, tartışma ve öneriler bölümlerine katkıda bulunmuştur. Araştırmanın yayın sürecine hazırlanması ve hakem değerlendirmeleri ile ilgili tüm süreçler ise birinci yazar tarafından gerçekleştirilmiştir. Yazarların araştırmaya katkı oranları \%50'dir.

Etik Kurul Kararı: Çukurova Üniversitesi Etik Kurul Komisyonunun 16.09.2020 tarihli 109487 sayll kararında etik açıdan uygun olduğu belirtilmiştir (Evrak Sayı: 917705517-604.02.02/).

Çatışma beyanı: Araştırmada, yazarların kendi içinde ve diğer kişi/kurum/kuruluşlarla herhangi bir çıkar çatışması söz konusu değildir.

Destek ve teşekkür: Bu araştırmanın yürütülmesinde herhangi bir kurum ya da kuruluştan destek alınmamıştır. Araştırmaya katılan değerli öğrencilerimize ve öğretmenlerimize teşekkür ederiz.

\section{Kaynaklar}

Ahmad, A., Tarmizi, R. A., \& Nawawi, M. (2010). Visual representations in mathematical word problem solving among form four students in Malacca. Procedia-Social and Behavioral Sciences, 8, 356-361.

Anwar, R. B., \& Rahmawati, D. (2017). Symbolic and verbal representation process of student in solving mathematics problem based Polya's stages. International Education Studies, 10(10), 20-28. 
İlkokul Öğrencilerinin Sözel Problem Çözerken Kullandıkları Görsel..

https://doi.org/10.5539/ies.v10n10p20

Battista, M. T. (1990). Spatial visualization and gender difference in high school geometry. Journal for Research in Mathematics Education,21, 47-60. https://doi.org/10.2307/749456

Boonen, A. J., van Wesel, F., Jolles, J., \& van der Schoot, M. (2014). The role of visual representation type, spatial ability, and reading comprehension in word problem solving: An item-level analysis in elementary school children. International Journal of Educational Research, 68, 15-26. https://doi.org/10.1016/j.ijer.2014.08.001

Campbell, K. J., Collis, K. F., \& Watson, J. M. (1995). Visual processing during mathematical problem solving. Educational Studies in Mathematics, 28(2), 177-194.

Çilingir- Altıner, E., \& Doğan, M. C. (2018). Investigating the spatial reasoning skills of students in the context of mathematical thinking profiles. European Journal of Education Studies. 50(1), 26-38

Deliyianni, E., Monoyiou, A., Elia, I., Georgiou, C., \& Zannettou, E. (2009). Pupils' visual representations in standard and problematic problem solving in mathematics: Their role in the breach of the didactical contract. European Early Childhood Education Research Journal, 17(1), 95-110.

Edens, K., \& Potter, E. (2008). How students unpack the structure of a word problem: Graphic representations and problem solving. School Sciences and Mathematics, 108, 184-196. http://dx.doi.org/10.1111/j.19498594.2008.tb17827.x

Elia, I., \& Philippou, G. (2004). The functions of pictures in problem solving. . Proceedings of the 28th Conference of the International Group for the Psychology of Mathematics Education, 2, 327-334.

Ergan, S. N. \& Özsoy, G. (2021). İlkokul dördüncü sınıf öğrencilerinin problem çözme sürecinde oluşturduğu görsel temsillerin incelenmesi. Dokuz Eylül Üniversitesi Buca Eğitim Fakültesi Dergisi , (51), 57-75. http://dx.doi.org/10.53444/deubefd.763452

Friedman, L. (1995). The space factor in mathematics: gender differences. Review of Educational Research, 65 (1), $22-50$.

Garzon, J. R., \& Casinillo, L. F. (2021). Visualizing mathematics: the use of block models for strategic problem solving. Journal of Education Research and Evaluation, 5(1), 112-117.

Guoliang, Y. (2003). Visual-spatial representations and mathematical problem solving among mathematical learning disabilities. Acta Psychologica Sinica, 35, 643-648.

Haciomeroglu, E. S., Aspinwall, L., \& Presmeg, N. C. (2009). Visual and analytical thinking in calculus. Mathematics Teacher, 103, 140-145. https://doi.org/10.5951/MT.103.2.0140

Haciomeroglu, E. S., Chicken, E., \& Dixon, J. K. (2013). Relationships between gender, cognitive ability, preference, and calculus performance. Mathematical Thinking and Learning, 15(3), 175-189. https://doi.org/10.1080/10986065.2013.794255

Hegarty, M., \& Kozhevnikov, M. (1999). Types of visual-spatial representations and mathematical problem solving. Journal of Educational Psychology, 91(4), 684.http://dx.doi.org/10.1037/0022-0663.91.4.68

Ho, S. Y., \& Lowrie, T. (2014). The model method: Students' performance and its effectiveness. The Journal of Mathematical Behavior, 35, 87-100. doi: 10.1016/j.jmathb.2014.06.002

Janvier, C., Girardon, C. \& Morand, J. (1993). Mathematical Symbols and Representations. In P. S. Wilson (Ed.), Research Ideas for the Classroom: High School Mathematics (pp. 79-102). Reston, VA: NCTM.

Johar, R., \& Lubis, K. R. (2018). The analysis of students' mathematical representation errors in solving word problem related to graph. Jurnal Riset Pendidikan Matematika, 5(1), 96-107.

Kılıç, Ç. (2009). Illköğretim beşinci sımı öğrencilerinin matematiksel problemlerin çözümlerinde kullandıkları temsiller. (Yayımlanmamış doktora tezi).. Anadolu Üniversitesi Eğitim Bilimler Enstitüsü, Eskişehir. 
Kozhevnikov, M., Hegarty, M., \& Mayer, R. (2002). Revising the visualizer-verbalizer dimensions: Evidence for two types of visualizers. Cognition and Instruction, 20, 47-77. https://doi.org/10.1207/S1532690XCI2001_3

Krawec, J. L. (2014). Problem representation and mathematical problem solving of students of varying math ability. Journal of Learning Disabilities, 47(2), 103-115.

Lean, G., \& Clements, M. A. (1981). Spatial ability, visual imagery, and mathematical performance. Educational Studies in Mathematics, 12, 267-299. https://doi.org/10.1007/BF00311060

Leonard, J. (2018). Culturally specific pedagogy in the mathematics classroom: Strategies for teachers and students. Routledge.

Lindner, M. A. (2020). Representational and decorative pictures in science and mathematics tests: Do they make a difference?. Learning and Instruction, 68, 101-345.

Lowrie T., \& Kay, R. (2001). Relationship between visual and nonvisual solution methods and difficulty in elementary mathematics. The Journal of Educational Research, 94, 248-255. https://doi.org/10.1080/00220670109598758

Lowrie, T. (2012). Visual and spatial reasoning: The changing form of mathematics representation and communication. In B. Kaur \& T. T. Lam (Eds.), Reasoning, communication and connections in mathematics: Yearbook 2012, Association of Mathematics Educators (pp. 149-168). Singapore: World Scientific.

Lowrie, T., \& Clements, M. K. (2001). Visual and nonvisual processes in Grade 6 students' mathematical problem solving. Journal of Research in Childhood Education, 16(1), 77-93.

Mainali, B. (2019). Investigating the relationships between preferences, gender, task difficulty, and high school students' geometry performance. International Journal of Research in Education and Science (IJRES), 5(1), 224-236.

Mainali, B. (2021). Preference for Solution Methods and Mathematical Performance: A Critical Review. International Electronic Journal of Mathematics Education, 16(3), em0651. https://doi.org/10.29333/iejme/11089

Mayer, R. E. (1985). Mathematical ability. In R. J. Sternberg (Ed.), Human abilities: An information processing approach (pp. 127-150). San Francisco, CA: Freeman.

Montenegro, P., Costa, C., \& Lopes, B. (2018). Transformations in the visual representation of a figural pattern. Mathematical Thinking and Learning, 20(2), 91-107.

Moses, B. E. (1977). The nature of spatial ability and its relationship to mathematical problem solving. (Yayımlanmamış doktora tezi). Ohio State University, Ohio.

NCTM (2000). Principles and standards for school mathematics. Reston, Va. NCTM

Nunokawa, K. (2005). Mathematical problem solving and learning mathematics: What we expect students to obtain. The Journal of Mathematical Behavior, 24(3), 325-340.

Pape, S. J., \& Tchoshanov, M. A. (2001). The role of representation (s) in developing mathematical understanding. Theory into practice, 40(2), 118-127.

Pitta-Pantazi, D., \& Christou, C. (2009). Cognitive styles, dynamic geometry, measurement performance. Educational Studies in Mathematics, 70, 5-26. https://doi.org/10.1007/s10649-008-9139-z

Presmeg, N. (2020). Visualization and learning in mathematics education. Encyclopedia of Mathematics Education, 900-904.

Presmeg, N. C. (1986). Visualisation and mathematical giftedness. Educational Studies in Mathematics, 17(3), 297-311. 
Rösken, B., \& Rolka, K. (2006, July). A picture is worth a 1000 words-the role of visualization in mathematics learning. In Novotná, J., Moraová, H., Krátká, M. \& Stehlíková, N. (Eds.). Proceedings 30th conference of the International Group for the Psychology of mathematics education (457-464 sayfa içinde) Prague: PME.

Stylianou, D. A. (2010). Teachers' conceptions of representation in middle school mathematics. Journal of Mathematics Teacher Education, 13(4), 325-343.

Stylianou, D. A., \& Silver, E. A. (2004). The role of visual representations in advanced mathematical problem solving: An examination of expert-novice similarities and differences. Mathematical thinking and learning, 6(4), 353-387.

Suwarsono, S. (1982). Visual imagery in the mathematical thinking of seventh grade students. (Yayımlanmamıs doktora tezi)., Monash University. Melbourne

Uesaka, Y., Manalo, E., \& Ichikawa, S. I. (2007). What kinds of perceptions and daily learning behaviors promote students' use of diagrams in mathematics problem solving?. Learning and Instruction, 17(3), 322335.

van Garderen, D., \& Montague, M. (2003). Visual-spatial representation, mathematical problem solving, and students of varying abilities. Learning Disabilities Research \& Practice, 18(4), 246-254.

Zahner, D., \& Corter, J. E. (2010). The process of probability problem solving: Use of external visual representations. Mathematical Thinking and Learning, 12(2), 177-204. 


\section{EXTENDED ABSTRACT}

\section{Introduction}

Representation, which has an important place in mathematics education, comprises the products, signs, and objects that individuals create during a mathematical activity or that they create in their minds (NCTM, 2000). Although some problems can be solved effectively with a visual or verbal approach, it is necessary to know the type of problem, its complexity, the knowledge of past life, and the level of success of the person to fully understand why the person chooses the different method when solving a problem.

Visual representations are known to play a vital role in the process of processing information. At the same time, visualization is seen as an important communication tool (Deliyianni et al., 2009). Visual representations are created with diagrams, shapes, or picture representations. Non-visual representation is a method that does not contain visual representations as an important part of the solution method. Non-visual solutions are created with symbolic or verbal representations.

When this field was examined in the summer, it was seen that many studies have been carried out on visual and non-visual representation types, but different results were reached in each study related to the representations preferred by the students in the face of different questions. In some studies, the students used visual representations to solve difficult problems (Uesaka et al., 2007; Ho and Lowrie, 2014), while in other studies, it was observed that they preferred non-visual representations in difficult and complex problems (Elia and Philippou, 2004; Stylianou and Silver, 2004; Uesaka et al., 2007). Unlike other studies, this study sought to examine the impact of this controversial situation on students in Turkey. In this direction, it was aimed to determine the visual and non-visual representations that students use to solve verbal problems and examine whether the default differences between these representations predicted verbal problem-solving performance. For this purpose, the following questions were sought to be answered.

1. What types of visual and non-visual representation do students use when solving verbal problems? What type of representation do they use when giving the correct answers?

2. Do the types of representations that the students use in verbal problem solving procedural procedures predict the problem-solving performance of the students?

\section{Method}

Herein, the mixed-nested design, in which the qualitative and the quantitative research methods are used, was preferred. In this direction, thematic and relational models were used together. Included in the study were 225 4th-graders. As for verbal problems, an 11-question Mathematical Processing Test was used. To allow the students to perform the necessary arithmetic procedures and exclude the possibility that the verbal problem was a decisive factor in problem-solving, the questions in the test were created from easy and appropriate questions for the level of the students. The internal consistency of the test in previous studies was 78 , while the Cronbach alpha value for this study was 0.87 . The reliability of the test is determined based on the Cohen Kappa value $(\mathrm{K}=0.96, \mathrm{P}<0.001)$.

Thematic analysis was used to examine which visual and non-visual representation types the students preferred while solving verbal problems and whether they answered the questions correctly as a result of these choices. At another stage, multiple regression analysis was conducted to determine whether the types of representations used by the students in the verbal problem-solving predicted their problem-solving performance. It was seen that the necessary assumptions for the multiple regression analysis were met (Binary correlation $<0.80 ; \mathrm{R} 2>0.20 ; \mathrm{CI}>30$; VIF $>10$ ).

\section{Results}

In easy problems, it has been seen that students prefer to solve problems from the mind more, and the rate of answering the question correctly is high, no matter which representation they choose. In solving more difficult questions, it was seen that the students preferred to use symbolic representation, but when the students solved these questions with schematic representation, it was seen that the rate of answering the 
questions correctly was higher. Similarly, as a result of the analysis conducted by Boonen et al. (2014), only the use of correct visual-schematic representations gave more correct answers to a verbal problem when compared to the other types of representations (non-visual, pictorial representations), while those who used pictorial and non-visual representations gave more incorrect answers. On the contrary, Lowrie and Kay (2001) stated that the representations that the students preferred while solving verbal problems varied according to the difficulty of the problems, and the students preferred to use visual representations to solve difficult problems.

In addition, as a result of the multiple regression analysis, it can be said that using schematic representation predicted problem-solving performance more effectively. Similarly, Boonen et al. (2014) determined in their study that when students use a correct visual-schematic representation, it increased their chances of solving a verbal problem correctly by about six times. According to another finding of the study, symbolic representation and mental solution variables were not significant predictors of problem-solving performance.

\section{Conclusion}

According to the results of the study, the reason why the students did not use visual representations may have been because they found it to be unnecessary or too difficult to create visual representations during mathematical verbal problem solving, or the students were had not been taught the use of visual representations effectively. It is noteworthy that the students used visual representation in $18 \%$ of the solutions to represent and solve a verbal problem. It is worrying that the students who used schematic representations showed that their problem-solving performance improved when compared to non-visual representation. The reason for this is that, according to Johar and Lubis (2018), a high percentage of students use the representations incorrectly; they are not used to problems that require representation; they are not used to solving problems in the form of problems asked in international exams, such as PISA and TIMSS; teachers are not routinely used the multiple representations during teaching. This is because the student is not used to solving problems. The students' choice mostly depends on what their teachers have taught them in class. For this reason, the advice herein to teachers is to be careful about representations that can help students understand and solve mathematical verbal problems, and be prepared for how visualization can be integrated into mathematics teaching and learning in their classrooms.

Developing only one-sided preferred representation of mathematical problem solving results in students having narrow mathematical development, as they do not have the opportunity to view mathematical problems from another perspective. Therefore, teaching strategies in mathematics lessons should focus on improving the balance of the students' knowledge and skills between visual and non-visual solution representations. At the same time, it is important for teachers to use activities that will develop skills in which students can use different forms of representation. The students' choice of representation often depends on what their teachers have taught them in the classroom. For this reason, the advice herein to teachers is to be careful about representations that can help students to understand and solve mathematical verbal problems, and be prepared for how to integrate visual and non-visual representations into teaching and learning mathematics in their classrooms. In addition, it is recommended that the developers of mathematics programs should include the use of multiple representation types in their programs. In future studies, new research can be conducted to repeat such studies in different age groups and determine the factors that affect the student's choice of the representation types. 


\section{EK 1}

\section{Matematiksel İşlem Testi (MIT)}

1: Ahmet Meryem'den uzun, Jale'den ise kısadır. En uzun boylu kimdir?

2: Uçan balon ilk önce yerden 20 metre yükseldi. Sonra să̆a doğru 10 metre ilerledi, sonra 10 metre aşă̆ıya düştü. Daha sonra să̆a doğru 5 metre ilerledi ve sonunda düz bir şekilde yere düştü. Balon başlangıç noktasından ne kadar uzaktadır?

3: Bir atletizm yarışmasında Ahmet, Ayşe'nin 4 adım önündedir ve Ali ise Ahmet'in 3 adım arkasındadır. Ali, Ayşe'nin ne kadar önündedir?

4: Ali bir ă̆aç dikti ve sonra yol boyunca her 5 adımda başka bir ă̆aç dikti. Yolun uzunluğu 15 adım olduğuna göre Ali toplamda kaç tane ă̆aç dikmiştir?

5: Dilara, Sıla ve Onur'un doğum günleri 1 Ocaktır. Ancak Dilara, Sıla'dan 1 yaş büyüktür ve Dilara, Onur'dan 3 yaş küçüktür. Ĕ̆ger Onur 10 yaşında ise, Sıla kaç yaşındadır?

6: Deniz'in parası Canan'ın parasından fazladır. Mete'nin parası ise Canan'ın parasından azdır. Kimin parası daha fazladir?

7: Ayla'nın boyu 150 cm'dir. Bir gün yüzme havuzundayken dik durduğunda, vücudunun 28 cm'sinin suyun üzerinde olduğunu belirledi. Buna göre havuzun derinliği kaç cm dir?

8: İki ă̆açta başlangıçta 4'er tane serçe vardır. Birinci ağaçtaki iki serçe uçarak ikinci ă̆aca geçiyor. Buna göre ikinci ă̆açtaki serçe sayısı birinci ă̆açtakinden ne kadar fazladır?

9: Mustafa atını 2 inek karşılı̆̆ında Halil'e verdi. Daha sonra, Mustafa her bir ineğini 3 koyun karşıllğ̆ında Ayşe'ye verdi. Buna göre Mustafa kaç tane koyun almıştır?

10: İrem, 30km'lik bir yolculuğa çıktı. Yolun ilk 5km'sini yürüdü. Daha sonra bir taksiye bindi. Taksi şoförü Irem'i bıraktığında gideceği yolun yarısını bitirmişti. Irem taksi ile ne kadar seyahat etmiştir?

11: Terazinin bir tarafında üç kavanoz reçel ve $1 \mathrm{~kg}$ ă̆ırlık vardır. Diğer tarafında ise $2 \mathrm{~kg}$ ve $5 \mathrm{~kg}$ ă̆ırlıklar vardır. Terazi bu şekilde dengededir. Bir tane kavanoz reçelin ă̆ırlı̆̆ı kaçtır? 